Article

\title{
Islam and Political Violence
}

\section{John L Esposito}

Prince Alwaleed Bin Talal Center for Muslim-Christian Understanding Georgetown University, Washington, DC 20057, USA; E-Mail: jle2@georgetown.edu

Academic Editor: Peter Iver Kaufman

Received: 31 July 2015 / Accepted: 21 August 2015 / Published: 10 September 2015

\begin{abstract}
The global threat of Al Qaeda post 9/11 and ISIL, increased Sunni-Shia conflicts, and violence in the Middle East and Pakistan dominate headlines and challenge governments in the region and globally. Both Muslim extremists and some Western experts and observers speak of a clash of civilizations or a culture war in Muslim-West relations. Both the discourse and violence yet again raise questions about the relationship of Islam to violence and terrorism: is Islam a particularly violent religion? Critics cite Quranic passages, doctrines like jihad and events in Muslim history as strong indicators and proof that Islam is the primary driver of Muslim extremism and terrorism. What do the Quran and Islamic law have to say about violence, jihad and warfare? What are the primary drivers of terrorism in the name of Islam today? This article will address these questions in the context of development of global jihadist movements, in particular $\mathrm{Al}$ Qaeda and ISIL, their roots, causes, ideology and agenda.
\end{abstract}

Keywords: violence; Quran; Sword-verses; Jihad; Al Qaeda; ISIL; Religious Terrrism; Caliphate; Islamic State; Sunni-Shia Sectarianism; Suicide bombing

The global threat of Al Qaeda post 9/11 and ISIL, increased Sunni-Shia conflicts and violence in the Middle East and Pakistan, Boka Haram terror in Nigeria, and domestic attacks in France and the U.S. dominate headlines and challenge governments in the region and globally. Both Muslim extremists and Western experts and observers, speak of a clash of civilization or a culture war in Muslim-West relations. Both the discourse and violence yet again raise questions about the relationship of Islam to violence and terrorism: is Islam a particularly violent religion? Critics cite Quranic passages, doctrines like jihad and events in Muslim history as strong indicators and proof that Islam is the primary driver of Muslim extremism and terrorism. 


\section{The Quran and Violence}

Islam, like its monotheistic cousins Judaism and Christianity, is a religion whose sacred scripture, history and tradition include both peace and violence [1-3]. The prophets of the Bible and Quran (Joshua, David, Saul, and Muhammad) were also warriors/military leaders. Historically, all three monotheistic religious traditions, Judaism, Christianity and Islam, have justified violence in the name of self-defense, but followers have also legitimated both holy and unholy wars, wars of conquest and imperial expansion and made religious claims to the occupation of land in the name of God. While the great majority of believers read violent texts in their historical contexts, religious extremists and terrorists continue to site them as justification for their actions. Mainstream believers also, in the words of Philip Jenkins, often have "Holy Amnesia" when it comes to their sacred texts versus those of others. Thus, for example, while many (including hardline Christian ministers and political commentators) rush to refer to violent passages in the Quran as if this were a specific problem of Islam, they overlook much the much greater number of passages that command violence, murder and even genocide, in the Bible [4]. As Jenkins has noted: "Much to my surprise, the Islamic scriptures in the Quran were actually far less bloody and less violent than those in the Bible. ... By the standards of the time, which is the 7th century A.D., the laws of war that are laid down by the Quran are actually reasonably humane... Then we turn to the Bible, and we actually find something that is for many people a real surprise. There is a specific kind of warfare laid down in the Bible which we can only call genocide" [5-7].

Understanding violence in Quranic texts, as with all religious texts, requires reading the text within its historical context. In Arabia's tribal society and environment, tribal raids and warfare were considered normal and lawful unless a truce had been concluded between tribes. Chivalry forbade killing noncombatants like children, women, religious leaders and old people. These rules were later incorporated into Islamic law and the doctrine of jihad.

From 622 until his death ten years later, Muhammad very successfully consolidated his power in Medina and united the feuding tribes of Arabia. At critical points throughout these years, Muhammad received revelations from God that provided guidelines for the jihad. As the Muslim community grew, questions about who had religious and political authority, how to handle rebellion and civil war, what was proper behavior during times of war and peace, how to rationalize and legitimate expansion and conquest, violence and resistance — all quickly emerged. Answers to these questions were developed by referring to Quranic injunctions.

The Quran provides detailed guidelines and regulations regarding the conduct of war: who is to fight and who is exempted (48:17, 9:91), when hostilities must cease (2:192), how prisoners should be treated. (47:4) Verses such as Quran 2:194 emphasize proportionality in warfare: "whoever transgresses against you, respond in kind." Other verses provide a strong mandate for making peace: "If your enemy inclines toward peace then you too should seek peace and put your trust in God" (8:61) and "Had Allah wished, He would have made them dominate you and so if they leave you alone and do not fight you and offer you peace, then Allah allows you no way against them" (4:90). From the earliest times, it was forbidden to kill noncombatants as well as women and children and monks and rabbis, who were given the promise of immunity unless they had taken part in the fighting. 
Under the leadership of Muhammad and then his early successors (caliphs), the Islamic community spread rapidly, creating a vast empire greater than Rome at its zenith and stretching from North Africa to India. Muslim armies, motivated both by economic rewards from the conquest of richer, more developed societies, and religious zeal, the promise of reward in heaven, successfully overran the Byzantine and Persian empires which had become exhausted from endless warring with each other.

The religious rationale (as distinct from the practical political and economic motives) for conquest and expansion was not to force conversion to Islam upon other faiths who had their own prophets and revelations. The Quran states clearly "There is no compulsion in religion" (2:256) but rather to spread its righteous order so that ignorance and unbelief could be replaced by just societies throughout the world. The religious justification made for a jihad to propagate the faith is connected to Islam's universal mission to spread the word of God and the just reign of God's will for all humanity: "So let there be a body among you who may call to the good, enjoin what is esteemed and forbid what is odious. They are those who will be successful" (3:104) and "Of all the communities raised among men you are the best, enjoining the good, forbidding the wrong, and believing in God" (3:110).

\section{Jihad and Violence}

The history of the Muslim community from Muhammad to the present can be read within the framework of what the Quran teaches about jihad. There is no single doctrine of jihad that has always and everywhere existed or been universally accepted. Muslim understanding of what is required by the Quran and the practice of the Prophet regarding jihad has changed over time. The doctrine of jihad is not the product of a single authoritative individual or organization's interpretation. It is rather the product of diverse individuals and authorities interpreting and applying the principles of sacred texts in specific historical and political contexts. Muslims throughout the ages have discussed and debated and disagreed about the meaning of jihad, its defensive and expansionist as well as legitimate and illegitimate forms. Terrorists have hijacked Islam and the doctrine of jihad much as Christian and Jewish extremists have committed their acts of terrorism in their own unholy wars in the name of Christianity or Judaism.

The importance of jihad is rooted in the Quran. The Quranic meaning of jihad refers to the obligation incumbent on all Muslims to struggle or exert (jihad) oneself, to follow and realize God's will: to lead a virtuous life, to fight injustice and oppression, reform and create a just society and, if necessary, engage in armed struggle to defend one's community and religion. Quranic passages referring to jihad as armed struggle fall into two broad categories: defensive, those that emphasize fighting against aggression, and offensive or expansionist, a more general command to fight against all unbelievers and spread the message and public order, or Pax Islamica, of Islam. Muslims throughout the ages have discussed, debated and disagreed about the meaning of jihad, its defensive and expansionist, legitimate and illegitimate forms ([8]; [9], p. 119).

The Quran does not command or condone illegitimate violence and terrorism. At the same time, early Quranic verses did affirm the right to respond to aggression, and to counter persecution and attack by Meccan rivals: "Permission is given to those who fight because they were wronged. Surely Allah is capable of giving them victory. Those who were driven out of their homes unjustly, merely for saying 'Our Lord is Allah'." Q. 22:39-40. Muslims are urged to fight with great commitment so that 
victory will come and battle will end: "If you meet them in battle, inflict on them such a defeat as would be a lesson for those who come after them, and that they may be warned" (8:57). However, as is noted in the same passage, if they propose peace, then the fighting must end: "But if they are inclined to peace, make peace with them, and have trust in God for he hears all and knows everything" (8:61). A similar message is found in the passage: "Fight for the cause of God with those who fight you, but do not be aggressive: God does not like aggressors" (2:190).

But what about the so-called "sword verses? The term "sword-verse" is not found in the Quran, or in major Prophetic traditions (hadith). This term represents a later interpretation of the Quran and Islamic law, developed by late eighth/early ninth century religious scholars (ulema), many of whom enjoyed royal patronage. Religious scholars annulled earlier Meccan Quranic verses in favor of the more militant verses revealed in Medina and then rulers employed these verses in Islamic law to legitimate their military jihads of conquest and imperial expansion in the name of defending and spreading Islam.

Quran 9:5 is the major sword-verse cited: "When the sacred months have passed, slay the idolaters wherever you find them, and take them, and confine them, and lie in wait for them at every place of ambush." [10]. Quran 9:5 responded to the context in which it was revealed; it was referring to Meccan non-Muslims, the pagans or polytheists of Arabia, not to Jews and Christians whom the Qur'an always refers to as the "People of the Book" ("Ahl al-Kitäb"). In contrast to the earliest commentators, as noted above, later medieval commentators reinterpreted this verse and expanded its meaning to justify wars of imperial expansion, a jihad against all non-Muslims.

Today, the meaning and intent of Q. 9:5 is distorted by both polemical critics of Islam and Muslim terrorists alike. Critics cite this verse to demonstrate that the religion of Islam is a violent religion that commands the killing of Jews and Christians. Muslim extremists and terrorist groups, past and present, like Al Qaeda, ISIS and Boka Haram, have used this verse to justify unconditional warfare against all unbelievers, non-Muslims as well as Muslims who do not accept their militant beliefs. Both conveniently overlook or reinterpret the end of Q. 9:5 which clearly states that, while Muhammad's followers had permission to fight to defend themselves, they were to stop if the enemy stopped its aggression: "But if they repent, perform the prayer and pay the zakat, then let them go their way, for God is forgiving and kind" (9:5).

\section{Muslims Attitudes towards Jihad Today}

The multiple meanings of jihad across the Muslim world today are reflected in Muslim responses to a worldwide Gallup Poll's open-ended question, "Please tell me in one word (or a very few words) what 'jihad' means to you." Personal definitions of jihad included (in decreasing order of frequency) references to: "a commitment to hard work" and "achieving one's goals in life"; "struggling to achieve a noble cause"; "promoting peace, harmony or cooperation, and assisting others"; and "living the principles of Islam."

In four Arab nations (Lebanon, Kuwait, Jordan, and Morocco), the most frequent response was: "duty toward God", a "divine duty", or a "worship of God"- with no explicit militaristic connotation at all. In four non-Arab countries (Pakistan, Iran, Turkey, and Indonesia), a significant minority 
reported-“sacrificing one's life for the sake of Islam/God/a just cause", or "fighting against the opponents of Islam" and in Indonesia, it was expressed by an outright majority ([11], p. 33).

\section{Islam in Modern Muslim Politics and Its Relationship to Violence}

In the late twentieth century, Islamically-informed or buttressed ideologies, replaced Arab nationalism/socialism in the Arab world as the primary political ideology. During the 1950s and 1960s widespread dissatisfaction with Western-inspired liberal nationalism took its toll as monarchs and governments tumbled from power in Egypt, Libya, Syria, the Sudan, Iraq, and Algeria. All were based upon some form of Arab nationalism/socialism with its populist appeals to Arab-Islamic roots, stress on Arab unity, criticism of the failures of liberal nationalism and the West, and promise of widespread social reforms. Arab nationalist leaders like Egypt's Gamal Abd al-Nasser and his admirers like Sudan's Jafar al-Numeiry and Libya's Muammar Qaddafi came to power. Arab nationalism/socialism was discredited by the disastrous Arab defeat in the 1967 Arab-Israeli war, the failure of economic policies, and government corruption. Israel's crushing victory over the combined forces of Egypt, Jordan and Syria in the 1967 Six-Day War symbolized the depth of Arab and Muslim impotence and the failure of modern nation states in the Muslim world. Israel seized major pieces of territory, including the Sinai Peninsula and Gaza Strip from Egypt, the Golan Heights from Syria, and the West Bank and East Jerusalem from Jordan. The loss of Jerusalem, the third holiest city of Islam, was particularly devastating to Muslims around the world, making Palestine and the liberation of Jerusalem an Islamic, not just an Arab or Palestinian, issue.

1967 proved a turning point for many in the Arab world but also in South and Southeast Asia. Critics blamed Western political and economic models for their moral decline and spiritual malaise. Disillusionment with the West, and in particular with the United States, its pro-Israel policy, and its support for authoritarian rulers fed anti-Western feelings. Muslim religious leaders and activists believed their message had been vindicated, maintaining that the failures and troubles of Muslims were a result of turning away from God's revealed path and relying on the West. Many urged a return to the Islamic principles and values that had made Muslim countries so powerful throughout history. Muslims must reclaim their Arab-Islamic identity and heritage, history, culture and values. This quest for identity, a more historic and authentic identity, triggered a resurgence of religion in politics and society across the Muslim world, a force that continues to impact Muslim politics today [12].

From the 1970s onwards, Islam and Islamic movements became a major force in Muslim politics that has continued for decades, informed as much by politics as by religion, taking many shapes and forms.

From Africa, across the Middle East to South, Southeast and Central Asia, Islam became the primary language of political discourse and mobilization in many Muslim countries. Muslim rulers have appealed to Islam to enhance their legitimacy, rule, and policies. Mainstream Islamist movements and political parties appealed to Islam for legitimacy and to mobilize popular support. Islamists in subsequent years were elected president, prime minister, deputy prime minister, parliamentarians, and mayors. At the same time, extremist Islamist (also commonly referred to as jihadist or militant Salafi movements) organizations used violence and terrorism in the name of Islam to threaten and destabilize governments, attack government institutions, and terrorize populations. However different mainstream Islamists were from militants in their specific agendas and tactics, the primary drivers were political 
grievances with the appeal to religion as a source of identity, ideology, legitimation, and mobilization. The Muslim Brotherhood in Egypt, Jamaat-i Islami in Pakistan, Ennahda in Tunisia, the FIS in Algeria, Turkey's Welfare Party, and later the Justice \& Development Party (AKP) participated in elections as opposition parties; Hizbollah emerged in response to the Israeli invasion and occupation of southern Lebanon and HAMAS was founded soon after the first intifada in Palestine; Islamic Jihad (Egypt) in 1980 and Islamic Jihad Palestine in 1981.

\section{Roots and Development of Today's Global Jihadist Movements}

Since the last half of the 20th century, a globalization of jihad has occurred in religious thought and in armed struggles. On the one hand, jihad's primary Quranic religious and spiritual aspects - the "struggle" or effort to follow God's path, to lead a good life - remains central to Muslim spirituality. On the other hand, the concept of jihad has been used and misused; used by resistance and liberation movements and hijacked and misused by extremist and terrorist organizations to legitimate, recruit, and motivate their followers. The trajectory of jihadist movements has moved from a national to a transnational or global agenda.

From the late 1970s to the early 1990s, militant Muslim groups focused locally, within their own nations. With the exception of bombings at the World Trade Center in 1993 and in Paris in 1995, most movements, their members and targets were national (the near enemy), using violent attacks to destabilize and in time overthrow specific Muslim governments. America and Europe remained secondary targets, "the far enemy," due to their military and economic support for oppressive regimes. Why the transformation from a local to a global jihad?

The 1979-1989 Soviet-Afghan war marked a turning point; jihad went global to a degree never seen in the past. The war was waged during the Cold War at the very time that Western and many Muslim nations feared not only Communism but also Ayatollah Khomeini and Iran's export of its Islamic revolution. An unforeseen consequence and outgrowth of the Afghan war was the development of a global jihad ideology and movement(s) that came to see Afghanistan as but one step in a global war against what were seen as un-Islamic Muslim governments and the West. The policies of authoritarian Muslim regimes proved to be catalysts for radicalization, violence and terrorism not only nationally but also transnationally.

11 September 2001 heralded the global threat of Osama bin Laden and Al-Qaeda and the genesis of global movements and networks with a global agenda and use of violence and terror in the name of Islam. The global jihad by Osama bin Laden and Al-Qaida (The Base) against corrupt Muslim governments and the West emerged as the primary movement and model for others that subsequently emerged, including ISIL ISIS. Afghan Arabs moved on to fight other jihads in their home countries and in Bosnia, Kosovo, and Central Asia. Others stayed on or were trained and recruited in the new jihadi madrasas and training camps [13,14]. Al Qaeda, its affiliates and other terrorist groups represented a new form of terrorism, transnational in its identity and recruitment and global in its ideology, strategy, targets, and network of organizations, as well as economic transactions. Individuals and groups, religious and lay, have seized the right to declare and legitimate unholy wars in the name of Islam. 
The globalization of jihad was reflected in Bin Laden's fatwa signed by Ayman Al-Zuwahiri, his deputy and now leader of Al Qaeda, and two other radical Muslim leaders from Pakistan and Bangladesh: "Killing the Americans and their allies - civilians and military — is an individual duty for every Muslim who is capable of it and in every country in which it is possible to do so. This will continue until al-Aqsā Mosque and the Holy Mosque in Mecca have been liberated from their grip, and their armies have moved out of all the lands of Islam, being defeated and unable to threaten any Muslim" [15].

After the Afghan-Soviet War, in which Bin Laden was on the same side as the U.S. and many in the Arab world and global community, he became a sharp critic of American foreign policy, radicalized by the prospect of an American-led coalition in the 1991 Gulf War, the danger of substantial American military and economic involvement and a subsequent increased presence and influence of America in Saudi Arabia. Although Bin Laden appealed to Islam, his primary justification and appeal was to the grievances and popular causes of many in the Arab and Muslim world.

In his "A Declaration of War against the Americans" in 1996, Bin Laden declared he was fighting U.S. foreign policy in the Middle East and, in particular, American support for the House of Saud and the state of Israel. His goal, he said, was to unleash a clash of civilizations between Islam and the Zionist crusaders of the West. Bin Laden sought to provoke an American backlash that would radicalize the Muslim world and would topple pro-Western Muslim governments.

Al Qaeda and their affiliates, as ISIS and other militants today, go beyond classical Islam's criteria for a just jihad and recognize no limits but their own, employing any weapons or means, which they rationalize as due to the overwhelming force of the enemy, Muslim governments and their Western allies. They reject Islamic law's regulations regarding the goals and means of a valid jihad, that violence must be proportional, that only the necessary amount of force should be used to repel the enemy, and that innocent civilians should not be targeted, and that jihad must be declared by the ruler or head of state. Acts normally forbidden-such as stealing, murdering noncombatants, and terrorism - against non-believers and unsupportive fellow believers now seen as the enemies of God alike are seen as necessary and required, religiously legitimated in a cosmic war between good and evil, between the armies of God and Satan. For these extremists, Muslims who remain apolitical or resist - individual Muslims or governments - are no longer regarded as Muslims but rather as atheists or unbelievers, or enemies of God, against whom all true Muslims must wage holy war, or jihad.

\section{Islam and Suicide Terrorism}

Historically, suicide bombing is not exclusively associated with Islam, but is also associated with secular political groups who used it as a means to fight against a stronger enemy, be it in military, technological, or economic terms (the Tamil Tigers for whom suicide bombing was their primary weapon are a case in point). As witnessed in Northern Ireland, Sri Lanka, Israel, India, Lebanon, Palestine, Pakistan, post Saddam Iraq, Kashmir, Chechnya, the major goal has often been nationalist, to end the occupation of lands, force "foreign" military forces from what these movements regarded as their homeland. Two major types of Muslim suicide bombers can be distinguished: those who embrace martyrdom to achieve national goals identified as supported by Islam (Palestinian, Chechnyan, and Kashmiri activists) and transnational terrorist movements, in particular al-Qaida and ISIS. 
However, while terrorists use religious appeals to recruit volunteers, is religion the key catalyst? Contrary to the conventional wisdom, Robert Pape's groundbreaking study of suicide terrorism incidents from 1980 to 2003, concluded:

"From Lebanon to Sri Lanka to Chechnya to Kashmir to the West Bank, every major suicide-terrorist campaign - over 95 percent of all the incidents - has had as its central objective to compel a democratic state to withdraw" [16-18].

Suicide bombing and terrorism were not, and are not, simply driven by blind religious, ethnic or cultural hatred, but by real or perceived injustices, especially associated with occupation. Both self-described religious and even secular groups have framed their terrorist acts within a powerful religious medium. The Tamil Tigers, a non-religious Marxist-Leninist group, whose main tactic was suicide bombings, appealed to Tamil Hindu religious identity in their struggle for independence against Sinhalese Buddhists in Sri Lanka. Hamas, an acronym for the Islamic Resistance Movement (Harakat al-Muqāwamah al-'Islāmiyyah), which originated primarily to resist Israeli occupation and Hizbollah which emerged in response to the Israeli occupation in southern Lebanon repression appealed to religion to legitimate its actions. Even the Al-Aqsa Brigade, a secular Palestinian militia, like Hamas, used religion to legitimate its suicide bombings, choosing the name Al-Aqsa (a major mosque and religious site in Jerusalem) as well as calling its attacks "jihads" and its fallen "jihadists" or martyrs. In Iraq: suicide terrorism was unknown in Iraq before its invasion and occupation by the United States and Great Britain. However, suicide bombing became a widespread tactic, used by Sunni and Shii militias, in sectarian conflicts over power and to end American occupation.

\section{ISIS and Its Self-Proclaimed Caliphate}

ISIS, with its proclaimed global agenda and wanton use of violence and terror, is the most recent iteration of militant globalism. ISIS stands for the Islamic State of Iraq and Syria, also called the Islamic State of Iraq and the Levant or ISIL, and, more recently, just IS or Islamic State. Political conditions in Syria and Iraq, ethnic-religious/sectarian divisions in the region, and the failures of the U.S. and international community contributed to ISIS stunning if barbaric success. Bashar al-Assad's brutal military response to the "threat" of the Arab uprisings or Spring's seeming democratization wave and the slaughter of moderate Syrian opposition groups, paved the way for outside jihadist groups and heightened Sunni-Shia sectarian warfare. Saudi Arabia, Qatar and Turkey's initial support for militant Sunni jihadist groups like including ISIS rather than moderate anti-Assad groups, to fight a primarily political-driven proxy war in Syria against Assad, compounded the situation. In Iraq, Nouri al-Maliki's installing a Shiah-dominated government and political marginalizing Sunnis increased an already polarized situation and sectarian violence that resulted in former Sunni military officers joining ISIS and alienated some Iraqi Sunnis welcoming ISIS ([19], p. 339).

\section{But What about ISIS Islamic Pedigree and Vision?}

As an organization, ISIS originated from Al-Qaeda's group in Iraq, the Islamic State of Iraq (ISI). While there are similarities between ISIS and other terrorist groups like Al-Qaeda in their religious/ideological worldview and tactics, there are also distinctive differences. Terrorist groups and 
networks usually consist of relatively small numbers of fighters who strike and move on; their primary targets are the "near enemy" with the "far enemy" a distant second. Estimates of ISIS membership and fighters vary from 30,000 to 70,000 and, in contrast to Al-Qaeda, ISIS seeks to take and hold territory and create a proto-state. ISIS invades, occupies and governs areas as part of its version of a transnational caliphate. Populations are forced to publically pledge their allegiance (baya) to the caliphate in exchange for which they are offered a mafia-like version of "protection". For example, after driving out Iraqi security forces and capturing Ramadi, a predominantly Sunni city, in May 2015, ISIS consolidated its power and proceeded to govern and administer its would-be state, as it had from Raqqa and Deir al-Zour in Syria to Mosul, imposing its brutal version of law and order. Those who resisted were killed, often beheaded, mosques were seized and regulated; male residents were required to attend and pray. However, at the same time, ISIS operated as an efficient government providing jobs, goods and services, rebuilding the city's infrastructure, public works projects, repairing roads, restoring medical services, and providing food, fuel, and electricity [20].

ISIS offers a new and unique militant Salafi ideology/religious rationale to justify, recruit, legitimate and motivate many of its fighters to achieve its goals. Baghdadi has mythologized and reinvented his own idiosyncratic brand of Islam to legitimate, recruit and mobilize fighters for his military ideological movement. He has blended religion and politics into a more comprehensive religious ideology, with its symbols, slogans and discourse and promoted it through social media, and to a degree that neither AQ nor any other Islamist movement has done in modern times. On 29 June 2014, ISIS proclaimed itself a worldwide caliphate, the Islamic State (IS), with Abu Bakr al-Baghdadi its caliph. Baghdadi's commitment to the restoration of the Caliphate identified his movement and proto-state with an idealized period of history that many Muslims see as the Golden Age of Islam religiously, politically and culturally. The Caliphate symbolizes Muslim unity, governance and social justice that still evoke the glories of Islamic history, in the face of more recent centuries of Western invasions, occupation and colonialism [21]. ISIS (or IS) now extended its claim to religious, political and military authority over all Muslims globally. Implied in the creation of the Islamic State as a restoration of the caliphate was the illegitimacy of post WWI European colonial creation of modern Arab states and their rulers and thus the legitimacy of the Islamic State's expansionist agenda.

Baghdadi's Islam is religiously and organizationally monolithic, authoritarian and exclusivist: "One leader, One authority, One mosque: submit to it, or be killed." [22]. For Baghdadi, he as Caliph has sole and absolute decision-making authority over all Muslims, Muslim groups, movements and institutions. All mujahedeen and Islamic factions or affiliates are expected to swear allegiance to him as caliph and to the Islamic state. There is but one interpretation of sharia with no recognition of diverse schools of Islamic law. Sunni imams/religious leaders who resist ISIS occupation and disagree with its violent brand of Islam are crushed. ISIS takes over all mosques, often replaces the local preachers and imposes its hardline exclusivist interpretation of Islam with brutal consequences for Shiah and non-Muslims. Indeed, for Baghdadi Shiah are not true Muslims nor are Sunnis who disagree with him.

ISIS has been unrelenting in its persecution of Shia Muslims, Christians and Yazidis with hundreds of thousands killed and forced to flee from the villages. Driven by a ruthless indiscriminate anti-Shia sectarianism, ISIS targets Shiah with a vengeance, making no distinction between Shiah fighters and ordinary civilian Shiah. This policy is reinforced by senior ISIS officers, Sunni members of Saddam 
Hussein's military who lost their positions after the U.S. invasion and occupation of Iraq post Saddam Shiah rule, non-Muslim religious minorities, Yazidis and Christians, have been expelled from their villages in Iraq where they had lived for 14 centuries. Christians only other choice for survival is conversion to Islam.

ISIS has used total war without limits: extreme public violence, beheading and gruesome images to worn, subdue and punish captured populations as well as attract international media coverage, attention and ransom [23]. Historically, beheading was an all too common form of punishment, an instrument employed in early Islamic, European (in particular the guillotine in France) and Asian history by governments and terrorists. Public beheadings of criminals remains common in Saudi Arabia today and, although not common, it has been used by AQ in the beheading of American journalist Daniel Pearl and recently by Mexican cartels.

Ironically, Ayman al-Zawahri, Al-Qaeda's leader, has criticized Baghdadi's premature creation of a caliphate as well as Baghdadi's excessive and indiscriminate use of violence: the slaughter of ordinary (non-combatant) Shia and use widespread policy of beheadings.

\section{Religion as a Cause and Catalyst for Political Violence and Terrorism}

Major polls have consistently reported that Islam is a significant component of religious and cultural identity in Muslim countries and communities globally and thus the use of Islam by violent extremists as an instrument for legitimation and mobilization is not surprising. As the Gallup World Poll of Muslims (2001-2007) in some 35 countries reported, the most frequent response by those polled as to what they admire most about themselves was "faithfulness to their religious beliefs." The top statement they associated with Arab/Muslim nations was that "attachment to their spiritual and moral values is critical to their progress" [24]. However, a primary catalyst for extremism, often seen as inseparable from the threat to Muslim religious and cultural identity, is the threat of political domination and occupation.

While religion/Islam does play a significant role, political grievances also play a significant role, often intertwined with religion. ISIS execution videos, released (October 2006-April 2013 Al-Furqan Media Foundation), when ISIS called itself the Islamic State of Iraq, underscore the importance of political grievances as motivations to join: Western military invasion, occupation and support for authoritarian regimes, the Iraqi and Syrian governments' killing of tens of thousands of civilians and "crimes" committed by individuals/groups (Iraqi soldiers, police, and government workers). Both the Iraqi and Syrian governments and their oppositions have conflated political grievances and violence with Sunni-Shia sectarianism. "The Syrian and Iraqi regimes have deliberately and successfully portrayed the conflict as sectarian to discredit the opposition and unify non-Sunnis around the governments. Many in the opposition in turn have embraced sectarianism...British officials noted that ISIS atrocities have played well with certain segments among Muslim youth, particularly those already involved in criminal activity. ISIS also offers its fighters uniforms, has English-language media, and otherwise appeals to young Westerners" [25].

As in the recent past, so too today, these grievances have remained powerful among some 20,000 foreign recruits, including more than 5000 Europeans and Americans. 


\section{Legitimate vs. Illegitimate Uses of Violence}

A critical issue is the distinction between legitimate $v s$. illegitimate uses of religion and of violence. The role of Pope John Paul II and Catholicism in Eastern Europe or of U.S. chaplains and Christianity and Judaism in support of WWII and other wars was welcomed as constructive in contrast to the role of some Christian leaders in Serbia and Muslim leaders who supported extremist groups. Similarly, while it is common to say we reject any group that advocates or uses violence, most Muslims, like Jews and Christians and others, in fact accept as legitimate the use of defensive violence and violence in "just wars".

The line between movements of national liberation and terrorist organizations is often blurred or dependent upon one's political vantage point. America's revolutionary heroes were rebels and traitors for the British crown. We find many recent examples among people of many faiths: Catholics and Protestants in Northern Ireland; Bosniaks (Muslims), Serbian Orthodox and Croat Catholics in the Balkans; Christians and Muslims during the Lebanese civil war; and Sunni and Shii in post Saddam Iraq. The complexity of the issue of legitimate $v s$. illegitimate violence is reflected in the changing perceptions and fortunes of leadership. In the recent past, Menachem Begin and Yitzak Shamir, Jomo Kenyatta, Nelson Mandela, and Yasser Arafat and the PLO, were regarded by their opposition as terrorists leading terrorist movements. Yesterdays' terrorists may be just that — terrorists; or they may be judged by history as freedom fighters, statesmen, and even Nobel Laureates.

Religion becomes a vehicle for expressing moral outrage at the invasion and occupation of Muslim lands, repression by authoritarian "un-Islamic" governments, sectarian conflicts and legitimation for the use of force and violent. However, the profiles of militant Muslim groups in recent decades reveals diverse personal, religious, and socioeconomic profiles and motivations. Within weeks after 9/11, media reported, what they regarded to be a "stunning discovery" that the attackers were not all from the poor, uneducated or oppressed sectors of society nor were they all particularly religious.

Profiles of terrorists, from the $9 / 11$ attacks to the London bombings of 7/7 reveal that many were educated individuals from middle- and working-class backgrounds. Some were devout; others were not-some had frequented bars, red light distracts, etc. Most were not graduates of madrasas or seminaries but of private or public schools and universities, among them: Osama Bin Laden, Ayman al-Zawahiri, Muhammad Atta, and British-born Omar Sheikh, the terrorist kidnapper of the executed Wall Street Journal reporter Daniel Pearl.

Studies on radicalization, terrorism and global suicide bombings by the EC's European Network of Experts on Violent Radicalization (of which I was a member) post 9/11 and 7/7 on radicalization in Europe on terrorism and others have found that in most cases religion is not the primary source of most extremists' behavior. The drivers of radicalization are diverse and influenced by specific contexts. For example, the vast majority of Muslim populations in Europe are members of a visible ethnic minority. Their narratives are shaped by experiences such as xenophobia, anti-Islam and anti-Muslim bias and racism, lower employment and educational levels, lack of a sense of dignity and self-esteem. The results often include a sense of marginalization and alienation, moral outrage, and search for a new identity with a sense of meaning, purpose and belonging. In many cases, terrorists are neither particularly religiously literate nor observant though their issues may overlap. As the UK's MI5 briefing report on radicalization (2008), concluded, “far from being religious zealots, a large number of 
those involved in terrorism do not practice their faith regularly. Many lack religious literacy and could be regarded as religious novices." Contrary to conventional wisdom, the report concluded that, "a well-established religious identity actually protects against violent radicalization".

Many of the above characteristics can be found among ISIS foreign recruits. Like many recruits to other militant Muslim movements, Europeans and Americans who join ISIS are often not necessarily religiously literate or devout. The case of Yusuf Sarwar and Mohammed Ahmed, two jihadi wannabes who in July 2014 pled guilty to terrorism offences, are a not uncommon example. Before they set out from Birmingham to fight in Syria last May, they ordered two books online from Amazon, Islam for Dummies and The Koran for Dummies [26]. Similarly, "Overall, security officials believe that the decision to go fight in a foreign conflict is usually less an act of religious commitment than of young male rebellion and thirst for adventure. One intelligence official notes that many recruits "just want to fight in Syria" but are vague on why. "Only one percent know a theologian" or are informed on dogma in any way." ([25], p. 5; [27], pp. 53-94).

ISIS has attracted a diverse group of fighters, including: former senior Iraqi Sunni military officers, tribal leaders and anti-U.S. insurgents who have been alienated and radicalized by the policies of Iraq's Shii dominated government; Tunisians, Egyptians, and Uighurs; Americans and Europeans. ISIS message of brotherhood, community, purpose and meaning, fighting for an alleged noble and higher cause find a ready audience among European and American recruits, many of whom feel alienated and marginalized in their societies and seek a more meaningful and exciting life and cause. While Bin Laden and Al-Qaeda fighters have lived a life of more itinerant ascetic warriors of Islam, always on the move or on the run, often living in primitive conditions, away from wives, ISIS offers it members and new recruits not only a strong sense of identity, community, power, agency, adventure, and meaning but also paid salaries, the opportunity to meet and marry female recruits and raise a family, and other tangible benefits [28].

ISIS has been remarkably successful in tapping into these needs and benefits in their use of the Internet for recruitment globally. Its extraordinarily professional and effective use of the Internet, social media (Facebook and twitter), video games and magazine's such as Islamic State News-online to preach its message and attract followers has brought recruits, women as well as men, from Tunisia to the Philippines and Europe to America. Like recruits to other effective social movements, many of ISIS recruits, are drawn by a message and lifestyle that romanticizes and legitimates their mission and their brutality and excessive use of force. The slaughter and savagery of ISIS fighters are normalized by images of heroic jihadist warriors, their cause and exploits, in victoriously routing of the enemy or "enemies of Islam".

Like AQ and other militant Muslim groups or movements, ISIS is a symptom of much deeper systemic problems in the Arab world that must be addressed by Arab political and religious leaders, Arab societies and the West. There is a direct linkage between the spread of extremism and authoritarian and repressive governments on the one hand and Western double standards on the other. The fallout from the failure of the Arab Spring, crushing hopes for democratization; Egypt's military-led coup which overthrew a democratically elected president and restoration of authoritarianism with the massacre of civilians, brutal repression of the Muslim Brotherhood and secular activist opposition; the U.S. and European Union's ambivalent response; and restoration of aid to the Abdel Fatah el-Sisi regime have all been a gift to ISIS and other terrorists' propaganda and 
recruitment. U.S. and European strengthening of ties with authoritarian Arab allies to defeat ISIS at the expense of their espoused principles and support for the right to self-determination, democracy and human rights reinforces the image and reality of a Western double standard. The suppression of moderate Islamist and secular groups and parties by authoritarian regimes with the acquiescence or support of Western allies fuels political violence and the rise and spread of AQ, ISIS and their lookalikes.

Violence and terrorism in the name of Islam by a host of militant Muslim movements in recent decades is a product of historical and political factors, not simply religion or a militant Islamic theology/ideology. Focusing on reading the Quran or violent passages in the Quran can obscure the importance of the policies of authoritarian and oppressive regimes and their Western allies. Many contemporary Muslim religious scholars and leaders have denounced extremists' appeals to Islam and their acts of violence and terrorism, issued fatwas, supported madrasa reforms and de-radicalization programs [29]. However, in the long run, to break the cycle of Muslim violence and terrorism, Muslim governments and their Western allies must address the political conditions that terrorist movements exploit. Addressing real grievances of the population (such as occupation, authoritarianism, repression, tyranny, and corruption) will suck the air from the extremist organizations and ideologies.

\section{Conflicts of Interest}

The author declares no conflict of interest.

\section{References and Notes}

1. For discussions of the relationship between monotheism and violence, see Rodney Stark. One True God: Historical Consequences of Monotheism. Princeton: Princeton University Press, 2007.

2. Mark Jurgensmeyer. Terror in the Mind of God: The Global Rise of Religious Violence. Los Angeles: University of California Press, 2003.

3. Jessica Stern. Terror in the Name of God. San Francisco: HarperOne, 2009.

4. For mass killings and genocide passages, see, for example, 1 Samuel 15:1-9, Joshua 6:20-21, Deuteronomy 2:32-35 and 3:3-7.

5. Philip Jenkins, as quoted in Barbara Bradley. "Is the Bible more Violent than the Quran." NPR, 18 March 2010. Available online: http://www.npr.org/templates/story/story.php?storyId= 124494788 (accessed on 31 August 2015).

6. Philip Jenkins. Jesus Wars. San Francisco: HarperOne, 2011.

7. John Shelby Spong. The Sins of Scripture: Exposing the Bible's Texts of Hate to Reveal the God of Love. San Francisco: Harper Collins, 2006.

8. For a major recent study of jihad, see Asma Asfaruddin. Striving in the Path of God: Jihad and Martyrdom in Islamic Thought. New York: Oxford University Press, 2013.

9. M. Cherif Bassiouni. "Evolving Approaches to Jihad: From Self-Defense to Revolutionary Regime-Change Political Violence." Chicago Journal of International Law 8 (2007): Article 8.

10. Others verses include $2: 191,193 ; 4: 89,91 ; 8: 39 ; 9: 29$, and 66:9.

11. John L. Esposito, and Dalia Mogahed. "Battle for Muslims' Hearts and Minds: The Road Not (Yet) Taken." Middle East Policy 14 (2007): 27-41.

12. John L. Esposito. The Future of Islam. New York: Oxford University Press, 2010, p. 61. 
13. For excellent coverage of the origin and development of Al-Qaeda, see Peter L. Bergen. Holy War, Inc.: Inside the Secret World of Osama Bin Laden. New York: Free Press, 2002.

14. Lawrence Wright. The Looming Tower: Al-Qaeda and the road to 9/11. New York: Knopf, 2006, p. 122.

15. John L. Esposito. Unholy War: Terror in the Name of Islam. New York: Oxford University Press, 2002, pp. 2-21.

16. Robert Pape. "Why the Bombers are so angry at us." The Age, 2005. Available online: http://www.theage.com.au/news/opinion/why-the-bombers-are-so-angry-at-us/2005/07/22/11215 39145036.html (accessed on 31 August 2015).

17. Robert Pape. Dying to Win: The Strategic Logic of Suicide Terrorism. New York: Random House, 2010.

18. Robert Pape. Cutting the Fuse: The Explosion of Global Suicide Terrorism and How to Stop It. Chicago: University of Chicago, 2010.

19. Fawaz Gerges. "Isis and the Third wave of Jihadism." Current History, 2014. Available online: http://currenthistory.com/Gerges_Current_History.pdf (accessed on 31 August 2015).

20. Erin Cunningham. "Islamic State converting Ramadi into stronghold." The Washington Post, 2015, A08.

21. Graham Fuller. "Who's afraid of the Caliphate." Huffington Post, 2015. Available online: http://www.huffingtonpost.com/graham-e-fuller/isis-caliphate-meaning_b_5562600.html (accessed on 31 August 2015).

22. Alastiar Crooke. "You Can't Understand ISIS if you don't know the history of Wahhabism in Saudi Arabia." Huffington Post, 2014. Available online: http://www.huffingtonpost.com/alastaircrooke/isis-wahhabism-saudi-arabia_b_5717157.html (accessed on 31 August 2015).

23. Fawaz Gerges quoted in, "The Islamic State, can its savagery be explained?" $B B C$ News, 9 September 2014. Available online: http://www.bbc.com/news/world-middle-east-29123528 (accessed on 31 August 2015).

24. John L. Esposito, and Dalia Mogahed. Who Speaks For Islam? What a Billion Muslims Really Think. New York: Gallup Press, 2008, p. 86.

25. Daniel Byman, and Jeremy Shapiro. "Be Afraid. Be A Little Afraid: The Threat of Terrorism from Western Foreign Fighters in Syria and Iraq." Foreign Policy at Brookings 34 (2014): 12-13. Available online: http://www.brookings.edu/ /media/research/files/papers/2014/11/westernforeign-fighters-in-syria-and-iraq-byman-shapiro/be-afraid--web.pdf (accessed on 31 August 2015).

26. Mehdi Hasan. "What the Jihadists Who Bought 'Islam for Dummies' on Amazon Tell Us about Radicalisation." Huffington Post UK, 2014. Available online: http://www.huffingtonpost. co.uk/mehdi-hasan/jihadist-radicalisation-islam-for-dummies_b_5697160.html?utm_hp_ref=tw (accessed on 31 August 2015).

27. Thomas Hegghammer. "The Rise of Muslim Foreign Fighters: Islam and the Globalization of Jihad." International Security 35 (2010): 53-94. Available online: http://www.mitpressjournals. org.proxy.library.georgetown.edu/doi/pdf/10.1162/ISEC_a_00023 (accessed on 31 August 2015).

28. Audrey Kurth Cronin. "ISIS is Not a Terrorist Group Why Counterterrorism Won't Stop the Latest Jihadist Threat." Foreign Affairs, 2015. Available online: http://cf.linnbenton.edu/artcom/ 
social_science/clarkd/upload/ISIS\%20Is\%20Not\%20a\%20Terrorist\%20Group.pdf (accessed on 31 August 2015).

29. Charles Kurzman. "Islamic Statements against Terrorism.” Available online: http://kurzman.unc. edu/islamic-statements-against-terrorism/ (accessed on 31 August 2015).

(C) 2015 by the author; licensee MDPI, Basel, Switzerland. This article is an open access article distributed under the terms and conditions of the Creative Commons Attribution license (http://creativecommons.org/licenses/by/4.0/). 